\title{
Waterbirds as Bioindicators of Environmental Conditions
}

\author{
Juan A. Amat and Andy J. Green
}

\section{Introduction}

One of the aims of monitoring is to provide information for ecological assessment, which can provide early warning of changes that could negatively affect species or ecosystems (Burger 2006). Since it is impractical to monitor all biological and physical components, a few of them can be used as indicators of wider conditions. Biological components chosen with this aim are called bioindicators (e.g. Matsinos and Wolf 2003).

Several aspects of the ecology of waterbirds make them useful as bioindicators. First, waterbirds have been shown to track environmental variations, at short (months) and long (years) temporal scales, and at both species and community levels (e.g. Nudds 1983; Amat et al. 1985; Guinet et al. 1998; Abraham and Sydeman 2004; Almaraz and Amat 2004; Rendón et al. 2008). Second, because many species are top predators and several contaminants often accumulate along the trophic chain, such species may be used as indicators of changes occurring at lower trophic levels (e.g. Matsinos and Wolf 2003; Burger and Eichhorst 2005). And third, either the waterbirds themselves or their prey are exploited by humans (e.g. hunting and fisheries), so that hunting bags of waterbirds may be indicative of productivity in nesting areas (Miller et al. 1988) or breeding parameters of birds may inform on fish stocks (Einoder 2009).

In this chapter we give some examples of the usefulness of using waterbirds as bioindicators. We explain why in other cases the use of waterbirds as indicators may be more limited, and we also identify how the design of studies can improve the utility of indicators.

\footnotetext{
J.A. Amat (*) and A.J. Green

Department of Wetland Ecology, Estación Biológica de Doñana, Consejo Superior de Investigaciones Científicas, Calle Américo Vespucio s/n, 41092, Sevilla, Spain e-mail: amat@ebd.csic.es

C. Hurford et al. (eds.), Conservation Monitoring in Freshwater Habitats:
} 


\section{Waterbirds as Bioindicators of Environmental Conditions}

Several studies show that waterbirds may be used as bioindicators of conditions encountered in wetlands, at both local and regional spatial scales. A classical example is the response of some waterbirds to eutrophication of wetlands. In the Mar Menor lagoon of south-eastern Spain the great crested grebe, Podiceps cristatus, increased in abundance as eutrophication increased as a result of nutrient inputs into the wetland, resulting from intensification of agricultural practices in the basin of the lagoon (Fig. 5.1). A parallel change in the number of grebes was not recorded in other sites of Spain, indicating that the increase in the Mar Menor lagoon did not result from external factors affecting the population at other spatial scales (Martínez Fernández et al. 2005).

Another example of the effects of agricultural changes in wetlands is provided by coots in southern Spain. There, the red-knobbed coot, Fulica cristata, declined in the second half of the 20th century and is now threatened with extinction. This decline was largely attributed to changes in the agricultural practices in the basins of wetlands, which accelerated siltation rates, and therefore shortened hydroperiods, affecting the quality of food plants of coots. Indeed, the assimilation efficiency of coots was negatively affected when the quality of their food plants was low, which usually occurs in early summer when water levels start to decline (Varo and Amat 2008). Therefore, the population dynamics of red-knobbed coots over long periods

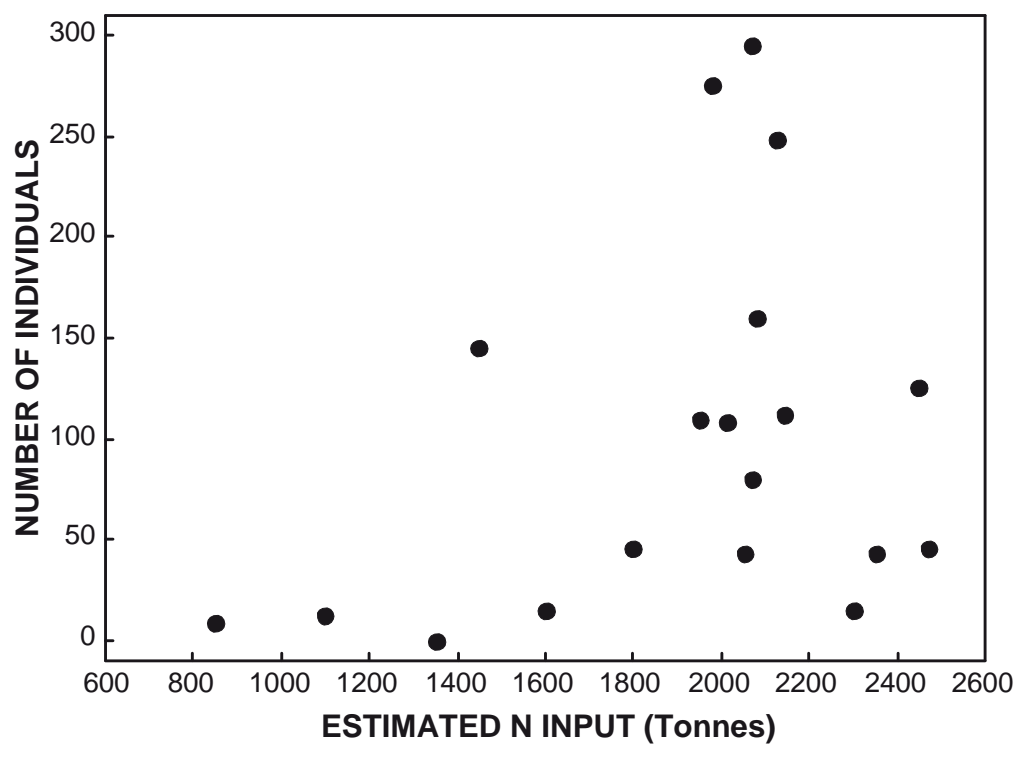

Fig. 5.1 Relationship between the number of great crested grebes Podiceps cristatus recorded at the Mar Menor lagoon (SE Spain) during January 1980-2001 and nutrient input estimates (tonnes of nitrogen) into the lagoon (modified from Martínez Fernández et al. 2005) 
(e.g. decades) could be used as indicative of changes occurring in wetlands at slow rates (e.g. siltation processes).

Agricultural changes may also have effects on waterbird habitats at large spatial scales. As a result of feeding on agricultural crops in winter and on migration, some populations of snow goose, Chen caerulescens, have increased by $7 \%$ per year and these increasing numbers have had a strong negative long-term effect on intertidal salt-marsh vegetation at an Arctic coastal breeding site, located 5,000 km from wintering sites. Here, goose grubbing caused loss of vegetation and salinity of bare ground precluded re-establishment of vegetation (Abraham et al. 2005).

Changes in the nutrient budget of wetlands are not only due to the effects of human activities, and may be a result of the activities of the birds themselves, as shown by research on northern fulmars, Fulmarus glacialis, nesting on cliffs above a coastal plain with freshwater ponds (Michelutti et al. 2009). Fulmars behaved as biovectors that transported important quantities not only of nutrients, but also of contaminants, from the sea to the ponds. These ponds contained more chlorophyll, chironomids, and contaminants than those not affected by bird activity. These indicators of bird activity could be used to track population changes in other bird species for which chironomids are an important food source (Michelutti et al. 2009).

The monitoring of breeding colonies of waterbirds may provide information on the conditions of wetlands used for feeding. The main colony of greater flamingos, Phoenicopterus roseus, in southern Spain is located at Fuente de Piedra lake, but the birds mainly forage in the Guadalquivir marshes, located $130 \mathrm{~km}$ from the nesting site (Rendón-Martos et al. 2000; Amat et al. 2005). Here, colony size was affected by water levels in the foraging site (Fig. 5.2).

\section{Limitations on the Use of Waterbirds as Bioindicators}

As shown above, there may be important relationships between waterbirds and biotic and abiotic factors of wetlands, and the effects of the birds in these habitats may have important consequences on food webs. This justifies the incorporation of waterbirds into biomonitoring programs. Nevertheless, some have questioned the usefulness of waterbirds as bioindicators (Green and Figuerola 2003; Piatt et al. 2008).

The main criticisms come from the lack of relationships between the diversity of waterbirds and that of other organisms. Community concordance measures the degree to which patterns in community structure in a set of sites are similar between different taxonomic groups (Paszkowski and Tonn 2000). Concordant patterns have been found among guilds of waterbirds, and even between waterbirds and fish in several lakes (Paszkowski and Tonn 2000, 2006), indicating that monitoring the status of one group may provide a useful bioindicator of the status of other groups (Paszkowski and Tonn 2006).

However, such patterns may not be so evident in other cases. For instance, the similarity among a set of lakes in southern Spain in their waterbird communities is 


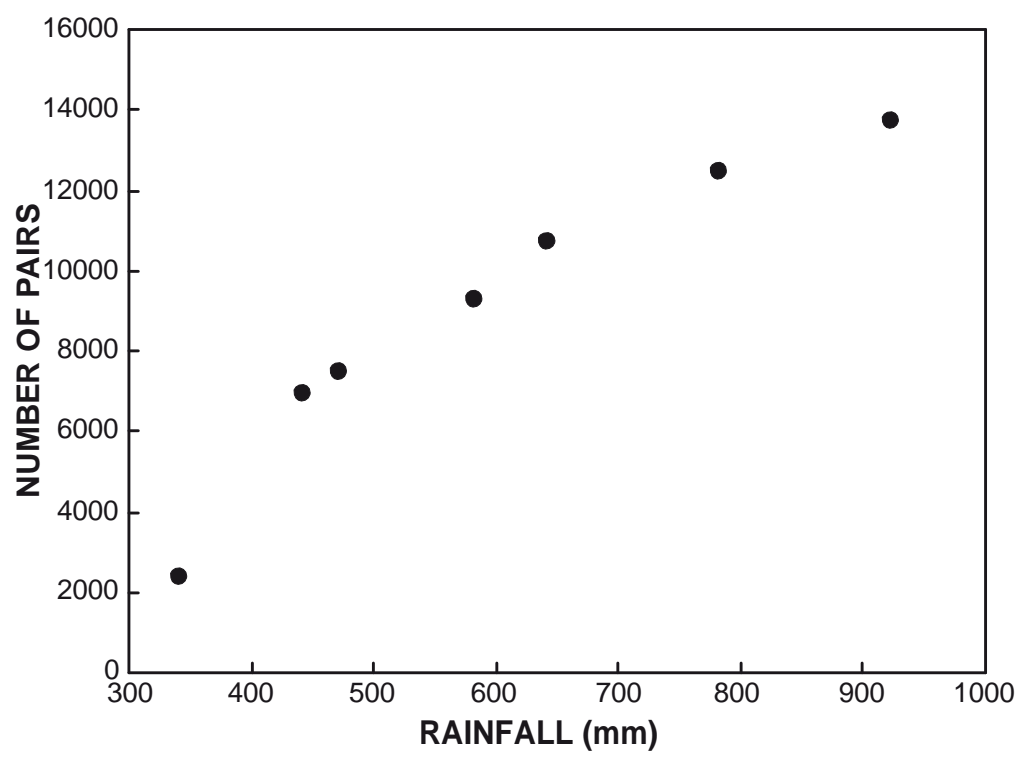

Fig. 5.2 Relationship between the size of a breeding colony of greater flamingos Phoenicopterus roseus at Fuente de Piedra lake and rainfall recorded during the preceding months at the marshes of the Guadalquivir in southern Spain (from Rendón-Martos 1996). The marshes are located 130 $\mathrm{km}$ from Fuente de Piedra, and are the main foraging site of flamingos breeding at the lake

very different to the similarities in their zooplankton or submerged macrophyte communities (Amat et al. 1985). Also in these lakes, the diversity of waterbird guilds (ducks, shorebirds) differs according to water levels (Amat 1984). In the case of highly dynamic wetlands, the responses to environmental variations may vary according to type of organisms, since different types of organisms may not perceive environmental variations in the same way. Under these circumstances, monitoring one group may not be a useful bioindicator of the status of another group.

Another difficulty of using waterbirds as bioindicators is related to their high mobility throughout the year. Migratory populations are subject to changes occurring not just in an area, but right across the migratory flyway. Even on a daily scale, their high mobility complicates their use as indicators. Although there may be a positive relationship between the size of wetlands and the number of waterbirds using them (Amat 1984; Nudds 1992; Weller 1999, Fig. 5.3), there are also cases in which such a relationship is not found, which may be explained in part by the differential use of wetlands throughout the day by waterbirds. Thus, many dabbling duck species use some wetlands for resting during the day, but forage in different wetlands during the night (Tamisier and Dehorter 1999). As waterbird counts are usually conducted during the day, trying to establish a relationship between biotic and abiotic factors of wetlands that are used as roosting sites and the carrying capacity of such wetlands for ducks may be misleading (Yésou 1983). 


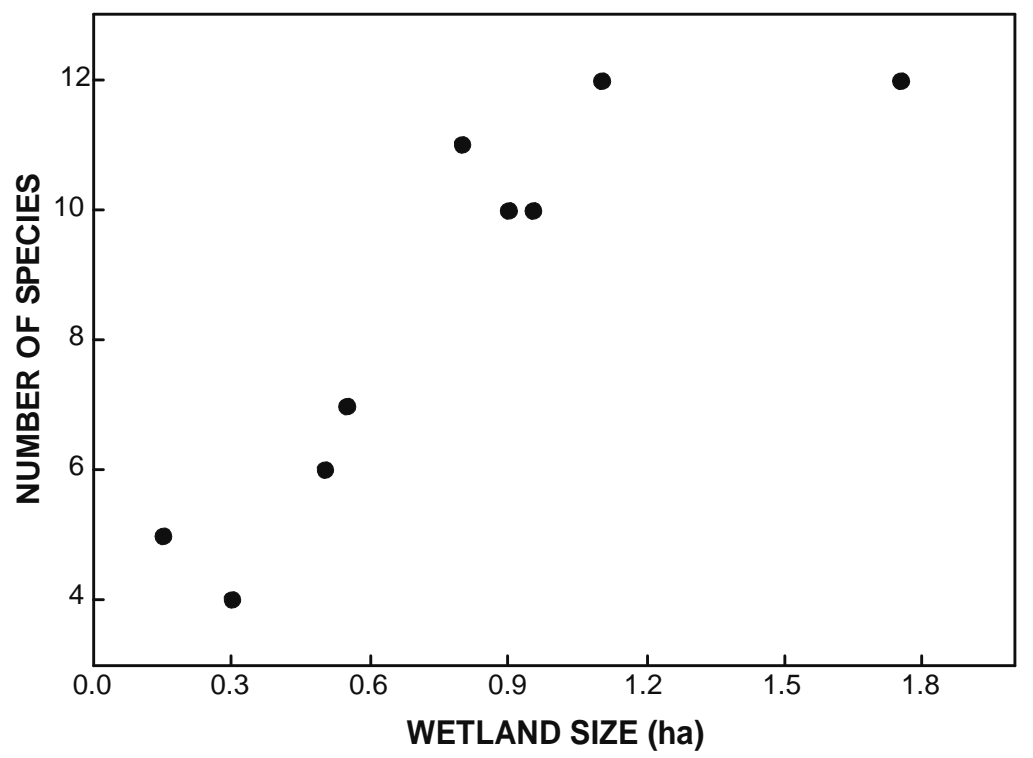

Fig. 5.3 Relationship between species richness of ducks and wetland size in Manitoba, Canada (modified from Nudds 1992)

Therefore, when considering the use of waterbirds as bioindicators, the identification of biologically meaningful parameters is vital. Also, because wetlands are highly dynamic ecosystems, it may be difficult to "capture” this variability by biomonitoring a single group of waterbirds. For a monitoring program to be successful, specific quantitative objectives should be defined, the objectives should be expressed as null hypotheses, and the sampling and analysis plan should be designed to test these hypotheses (Segar et al. 1985).

\section{Which Indicators Are More Relevant?}

There are species that indicate areas of high diversity, and others that measure environmental changes (Caro and O’Doherty 1999). The relevance of indicator species should depend on the aims of the monitoring program.

In the case of species indicating diversity hotspots, the monitoring of such species may be enough to assess the conservation status of the entire area. For instance, the red-knobbed coot is found in Morocco in wetlands with a high diversity of submerged macrophytes (Green et al. 2002). Here conserving the aquatic plants would ensure the conservation of the coot, but the monitoring of coots would be an efficient surrogate for the more difficult task of monitoring the vegetation. In the case of species that measure environmental change, some population parameters (e.g. nesting success, dynamics), may be used as indicators (e.g. Fig. 5.2). 
Because the natural environment affects many physiological processes, waterbird physiology can provide information to detect stressors and to predict possible negative effects on populations. For instance, interannual variations in the body condition of flamingo chicks are linked to variations in several blood parameters, which reflect the feeding conditions encountered by adults (Amat et al. 2007). Long-term temporal changes in diets can also be examined with the use of stable isotopes in both tissues of museum specimens and live individuals (Chamberlain et al. 2005; Becker and Beissinger 2006). The heat-shock protein response may have also applications in biomonitoring, because of their responsiveness to stressors (Feder and Hofmann 1999).

Traditionally, the most basic objective of biomonitoring has been to detect trends. Although in some countries there may be databases that cover long periods of time, in some other countries such information may be scarce. Errors in trend analysis may be more likely with limited databases and can have serious consequences. Hence, the trends detected by a monitoring programme should be evaluated with power analysis (Lougheed et al. 1999).

\section{Conclusions}

Birds are popular subjects for research and monitoring, and long-term datasets of waterbird counts often provide a useful resource as indicators of ecological change. However, different waterbird species undergo population fluctuations for different reasons, and a thorough knowledge of the ecology of a given species is required if trends are to be interpreted correctly. Waterbirds do not merely respond to environmental change, they can also be the cause of change as their populations increase, due to overgrazing or because they act as vectors of nutrients and contaminants. In some cases birds may not respond to wetland characteristics in the same way as other groups of organisms, in which case birds may not be considered as surrogates of other organisms in biomonitoring programs. In other cases, however, birds can be reliable indicators of nutrient status, fish stocks or the abundance of aquatic plants. As the difficulties inherent in monitoring some groups of organisms (e.g. aquatic vegetation) might be best avoided if a reliable indicator is available, in these last cases birds may be considered as relatively easily measurable surrogates. When using waterbirds as indicators, clear objectives for the monitoring programme are essential.

\section{References}

Abraham CL, Sydeman WJ (2004) Ocean climate, euphausids and auklet nesting: Inter-annual trends and variation in phenology, diet and growth of a planktivorous seabird. Marine Ecol Prog Ser 274:235-250

Abraham KF, Jefferies RL, Alisauskas RT (2005) The dynamics of landscape change and snow geese in mid-continent North America. Global Change Biol 11:841-855 
Almaraz P, Amat JA (2004) Multi-annual spatial and numeric dynamics of the white-headed duck Oxyura leucocephala in southern Europe: Seasonality, density-dependence and climatic variability. J Anim Ecol 73:1013-1023

Amat JA (1984) Las poblaciones de aves acuáticas en las lagunas andaluzas: Composición y diversidad durante un ciclo anual. Ardeola 31:61-79 (in Spanish)

Amat JA, Díaz Paniagua C, Herrera CM, Jordano P, Obeso JR, Soriguer RC (1985) Criterios de Valoración de Zonas Húmedas de Importancia Nacional y Regional en Función de las Aves Acuáticas. Instituto Nacional para la Conservación de la Naturaleza, Madrid, p 79 (in Spanish)

Amat JA, Rendón MA, Rendón-Martos M, Garrido A, Ramírez JM (2005) Ranging behaviour of greater flamingos during the breeding and post-breeding periods: Linking connectivity to biological processes. Biol Conserv 125:183-192

Amat JA, Hortas F, Arroyo GM, Rendón MA, Ramírez JM, Rendón-Martos M, Pérez-Hurtado A, Garrido A (2007) Interannual variations in feeding frequencies and food quality of greater flamingo chicks (Phoenicopterus roseus): Evidence from plasma chemistry and effects on body condition. Compar Biochem Physiol A 147:569-576

Becker BH, Beissinger SR (2006) Centennial decline in the trophic level of an endangered seabird after fisheries decline. Conserv Biol 20:470-479

Burger J (2006) Bioindicators: Types, development, and use in ecological assessment and research. Environ Bioindicators 1:22-39

Burger J, Eichhorst B (2005) Heavy metals and selenium in grebe eggs from Agassiz National Wildlife Refuge in northern Minnesota. Environ Monitor Assess 107:285-295

Caro TM, O’Doherty G (1999) On the use of surrogate species in conservation biology. Conserv Biol 13:805-814

Chamberlain CP, Waldbauer JR, Fox-Dobbs K, Newsome SD, Koch PL, Smith DR, Church ME, Chamberlain SD, Sorenson KJ, Risebrough R (2005) Pleistocene to recent dietary shifts in California condors. Proc Natl Acad Sci USA 102:16707-16711

Einoder LD (2009) A review of the use of seabirds as indicators in fisheries and ecosystem management. Fish Res 95:6-13

Feder ME, Hofmann GE (1999) Heat-shock proteins, molecular chaperones, and the stress response: Evolutionary and ecological physiology. Ann Rev Physiol 61:243-282

Green AJ, Figuerola J (2003) Aves acuáticas como bioindicadores en los humedales. In: Paracuellos M (ed) Ecología, Manejo y Conservación de los Humedales. Instituto de Estudios Almerienses, Almería, pp 47-60 (in Spanish)

Green AJ, El Hamzaoui M, El Agbani MA, Franchimont J (2002) The conservation status of Moroccan wetlands with particular reference to waterbirds and to changes since 1978. Biol Conserv 104:71-82

Guinet C, Chastel O, Koudil M, Durbec JP, Jouventin P (1998) Effects of warm sea-surface temperature anomalies on the blue petrel at the Kerguelen Islands. Proc Roy Soc Lond B 265:1001-1006

Lougheed LW, Breault T, Lank DB (1999) Estimating statistical power to evaluate ongoing waterfowl population monitoring. J Wildlife Manage 63:1359-1369

Martínez Fernández J, Esteve Selma MA, Robledano Aymerich F, Pardo Sáez MT, Carreño Fructuoso MF (2005) Aquatic birds as bioindicators of trophic changes and ecosystem deterioration in the Mar Menor lagoon (SE Spain). Hydrobiologia 550:221-235

Matsinos YG, Wolf WF (2003) An individual-oriented model for ecological risk assessment of wading birds. Ecol Model 170:471-478

Michelutti N, Keatly BE, Brimble S, Blais JM, Liu H, Douglas MSV, Mallory ML, Macdonald RW, Smol PL (2009) Seabird-driven shifts in Arctic pond ecosystems. Proc R Soc B 276: 591-596

Miller MR, Beam J, Connelly DP (1988) Dabbling duck harvest dynamics in the Central Valley of California - Implications for recruitment. In: Weller MW (ed) Waterfowl in winter. University of Minnesota Press, Minneapolis, MN, pp 553-569

Nudds TD (1983) Niche dynamics and organization of waterfowl guilds in variable environments. Ecology 64:319-330 
Nudds TD (1992) Patterns in breeding waterfowl communities. In: Batt BDJ, Afton AD, Anderson MG, Ankney CD, Johnson DH, Kadlec JA, Krapu GL (eds) Ecology and management of breeding waterfowl. University of Minnesota Press, Minneapolis, MN, pp 540-567

Paszkowski CA, Tonn WM (2000) Community concordance between fish and aquatic birds of lakes in northern Alberta, Canada: The relative importance of environmental and biotic factors. Freshwater Biol 43:421-437

Paszkowski CA, Tonn WM (2006) Foraging guilds of aquatic birds on productive boreal lakes: Environmental relations and concordance patterns. Hydrobiologia 567:19-30

Piatt JF, Harding AMA, Schultz M, Speckman SG, van Pelt TI, Drew GS, Kettle AB (2008) Seabirds as indicators of marine food supplies: Cairns revisited. Marine Ecol Prog Ser 352:221-234

Rendón MA, Green AJ, Aguilera E, Almaraz P (2008) Status, distribution and long-term changes in the waterbird community wintering in Doñana, south-west Spain. Biol Conserv 141:1371-1388

Rendón-Martos M (1996) La laguna de Fuente de Piedra en la Dinámica de la Población de Flamencos (Phoenicopterus ruber) del Mediterráneo Occidental. PhD Thesis, University of Málaga, Málaga p 386 (in Spanish)

Rendón-Martos M, Vargas JM, Rendón MA, Garrido A, Ramírez JM (2000) Nocturnal movements of breeding greater flamingos in Spain. Waterbirds 23(Special Publ. 1):9-19

Segar D, Phillips D, Stamman E (1985) Design of bioindicator based programs to monitor ocean status and trends. Oceans 17:926-931

Tamisier A, Dehorter O (1999) Camargue: Canards et Foulques. Centre Ornithologique du Gard, Nimes: p 369 (in French)

Varo N, Amat JA (2008) Differences in food assimilation between two coot species assessed with stable isotopes and particle size in faeces: Linking physiology and conservation. Compar Biochem Physiol A 149:217-223

Weller MW (1999) Wetland birds. Habitat resources and conservation implications. Cambridge: Cambridge University Press, p 271

Yésou P (1983) Anatidés et zones humides de France métropolitaine. Bulletin mensuel de l’Office National de Chasse, Numéro special, scientifique et technique, 1-315 (in French) 